\title{
ケーソン据付時の係留索に作用する張力特性 把握を目的とした現地計測の試み
}

\author{
小竹 康夫 1 後藤 $\quad$ 潤也 2 - 小倉 勝利 $3 \cdot$ \\ 阿部 覚 4 ・ 山口 陽介 $4 \cdot$ 加藤 直幸 5 \\ 1 正会員 東洋建設（株）鳴尾研究所（广663-8142 兵庫県西宮市鳴尾浜 1-25-1） \\ E-mail: kotake-yasuo@toyo-const.co.jp \\ 2 東洋建設（株）東北支店（＝９80-0021 仙台市青葉区中央 2-9-27） \\ E-mail: goto-junya@toyo-const.co.jp \\ 3 東洋建設（株）東北支店（产980-0021 仙台市青葉区中央 2-9-27） \\ E-mail: ogura-katsutoshi@toyo-const.co.jp \\ 4 東洋建設（株）東北支店（厂980-0021 仙台市青葉区中央 2-9-27） \\ 5 東洋建設（株）土木技術部（†135-0064 東京都江東区青海 2-4-24 青海フロンティアビル 12F）
}

\begin{abstract}
建設現場では，技術者の確保や若い世代一の技術の継承が課題となっている．本研究では，防波堤築造 工事において, 新設するケーソンを安全かつ高精度に据え付けるための係留ワイヤの取り付け方法やウィ ンチ操作技術に着目し，技術者の経駼值を数值化する試みの第一歩として，実施工を対象とした現地計測 を実施した。具体的には，防波堤ケーソンの据付作業において係留ワイヤに作用寸る張力を測定し，ウィ ンチ操作者および据付状況を撮影したビデオ映像から函の動摇を読み取って， ウィンチ操作と係留ワイヤ に作用する張力および函の動摇の関係を調べた。 その結果, 本研究で対象とした施工方法および波浪条件 では，引き寄せ時と着底時で大きな張力が作用するワイヤが異なること，引き寄せ時により大きな張力が 作用していた.
\end{abstract}

Key Words : mooring cable, tension, oscillation of a floating body, caisson installation, field measurement

\section{1. はじめに}

防波堤の築造工事において, 新しいケーソン (新設函) を据え付ける方法はいくつか存在する. その一例を図-1 に示す．多くの場合，新設函は防波堤から離れた製作ヤ ードで製作され，据付までの期間，海域に設けられた仮 置き場所に注水した状態で仮置きされる. その後, 図-1 のフローに示寸通り,仮置き場所で排水, 浮上させた後, 曳船により防波堤築造場所まで曳航し，据え付ける．据 付に際しては, 複数本の係留ワイヤで既設防波堤などと つないだうえで，注水作業により新設函を沈めながら， ウィンチ操作により平面的な位置を調整し, 基礎マウン ド上に着底させる．この間，常に波浪により新設函は動 摇した状態での作業となるため, ウィンチ操作による新 設函の動摇制御が，所定の位置に精度よく据え付けるた めの鍵となる.

据付時のケーソンの動摇制御に関する研究は，防波堤 設置位置の大水深化が進んだ1990年代に数多く実施され ている，堀沢ほか ${ }^{11}$ は，据付時に新設函が動摇すること

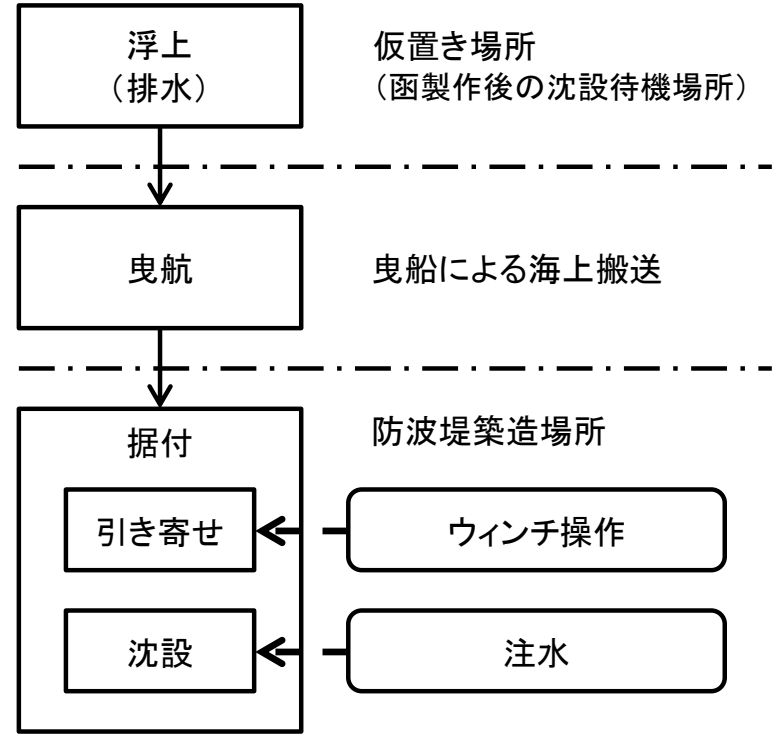

図-1 施工フローの一例 


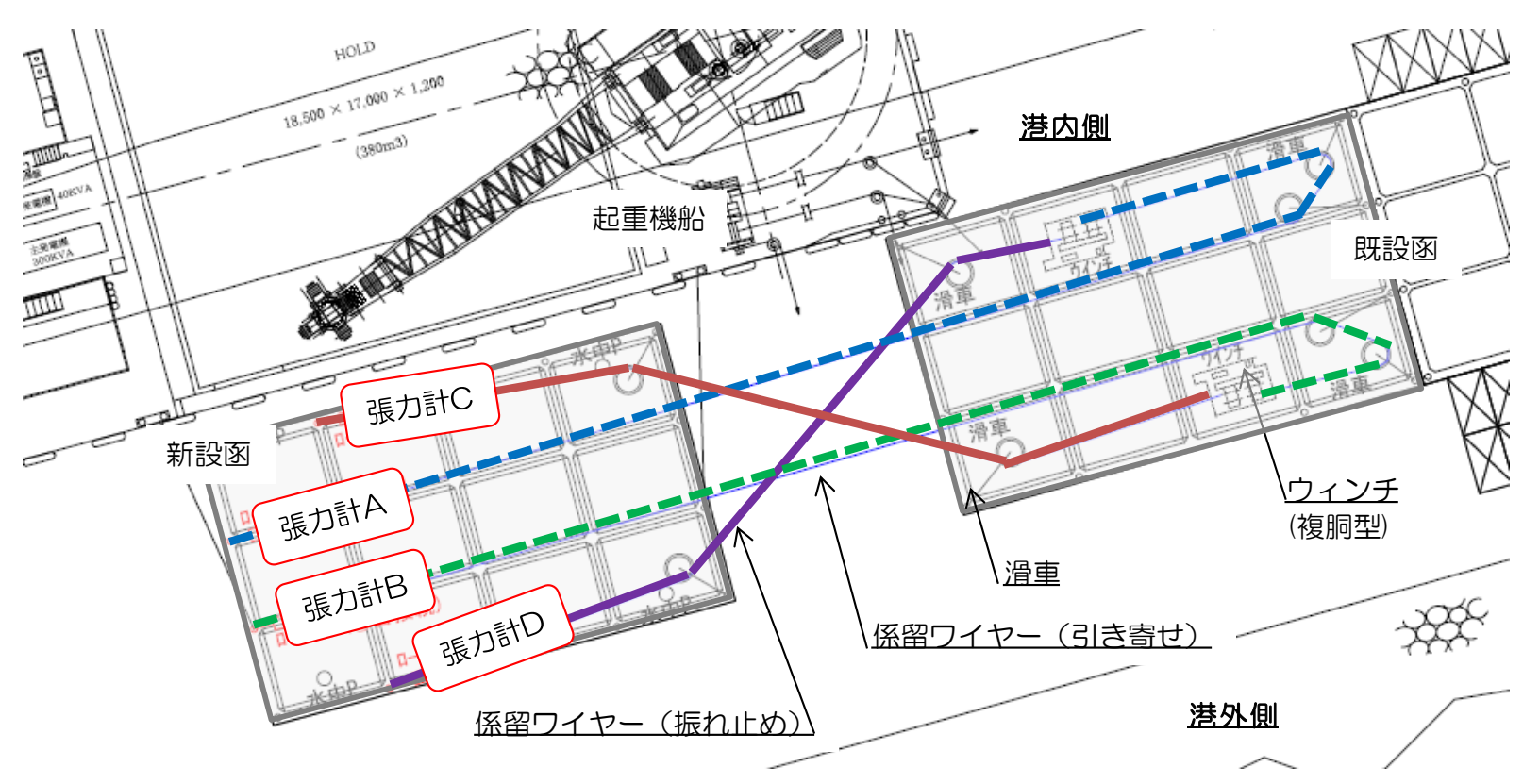

図-2 施工イメージと張力計の配置

により，ケーソン下端とマウンド天端が接触した状況を 考慮した計算を実施し，水理模型実験により計算結果の 妥当性を評価している．ただし現地作業の実態を十分に 把握できていないとの認識のもと, 堀沢ほか22)では実施 工時の現地調查を行い，動摇量と係留ワイヤに作用寸る 張力を評価している，一方，石見ほがは据付時の作業 限界に着目し，実施工における現地計測結果に対応する 動摇シミュレーションを拡張し, 他地域における限界動 摇量や限界波高などの作業可否判断指標を提示している。 また米山4) も同様に動摇シミュレーションにより，断面 形状の異なる複数のケーソンに対して，据付限界状態の 検討を行うなど, 波浪外力とケーソンの動摇量, 係留ワ イヤに作用する張力を取り扱う研究が見受けられる. ま た石嵪ほが は，施工中のワイヤ破断時の動摇量をスペ クトル解析することにより，破断原因を推定するととも に, 曳航時にまで検討手法を拡張し, 動摇量スペクトル と波浪外力の関係を評価している (石嵪ほかの).

ここで，ワイヤの破断は作業員の人命にかかわる重大 事故につながりかねず，係留ワイヤに作用する張力の評 価は安全面からも重要なパラメタであるが，波浪外力の みではなく, 係留ワイヤの引き込み, 送り出しなどの状 況にも影響を受けると考えられる. 係留ワイヤの引き込 みや送り出しは，ウィンチ操作者に対する指示者の指示 により実施されており, 熟練技術者の経験を必要とする 作業のひとつである.

しかしながら近年，建設現場では少子高齢化による技 術者不足や若い世代一の技術の継承が深刻な問題となっ ている. そこで本研究では，防波堤築造工事において， 新設するケーソンを安全かつ高精度に据え付けるための
係留ワイヤの取り付け方法やウィンチ操作技術に着目し， 技術者の経験值を数值化する試みの第一歩として，実施 工を対象とした現地計測を実施した。

\section{2. 現地計測の概要}

\section{(1) 対象工事の概要}

現地計測は，宮城県発注の女川湾口防波堤災害復旧 (その 5) 工事において施工管理の一環として実施した. この工事は，2011年東北地方太平洋沖地震津波により被 災した女川湾口に位置する混成堤式防波堤を復旧寸るも のであり，鉄筋コンクリート製函体（ケーソン）を捨石 マウンド上に据え付ける作業を計測対象とした. 施工イ メージと現地計測用の張力計配置を図-2に示す.

ケーソン据付作業での係留ワイヤの取り付け方法に はいくつかのパターンがあるが，今回対象とした工事で は，新設函を，据え付け済みのケーソン（既設函）に4 本のワイヤで係留し，ウィンチの操作で新設函を既設函 側に引き寄せながら，新設函に注水することで，所定位 置に着底させた.ここで4本のワイヤのうち防波堤法線に 平行な2本 (張力計 $\mathrm{A}, \mathrm{B}$ に対応) は, 防波堤法線方向の 引き寄せ，クロス掛けの 2 本（張力計C,Dに対応）は，防 波堤法線直角方向の振孔止めを目的としている.

なお図-2に示される通り，港内側には起重機船が一定の 離隔をとって新設函に横付けされている，そのため，新 設函の動摇量や係留ワイヤに作用する張力にも一定の影 響が見込まれるが，今回はそれらを考慮せずに検討する ものとした．したがって，起重機船の影響については 


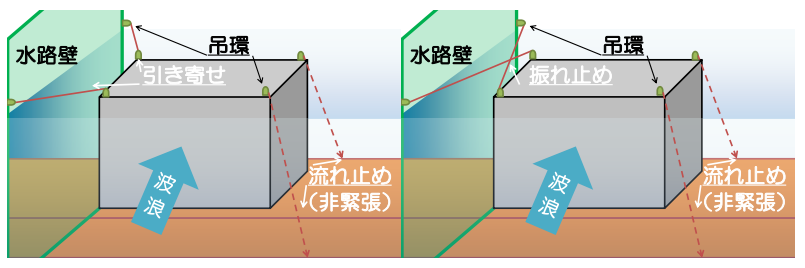

引き寄せ（AE）

振れ止め (AG)

(a) 係留ワイヤのモデル化

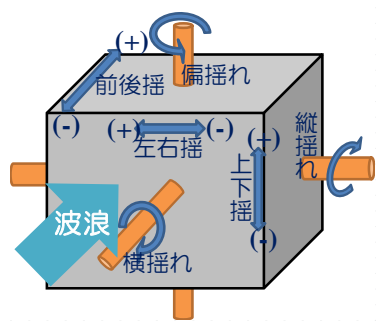

(b) 摇れの定義

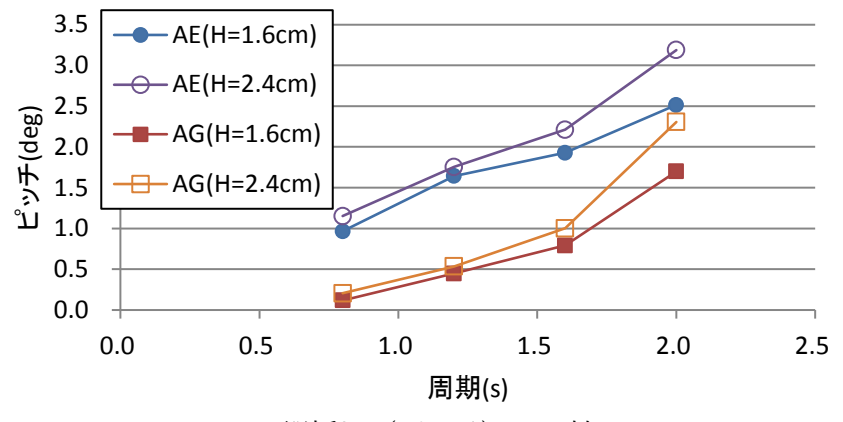

(c) 縦摇れ (ピッチ) の比較

図-3 事前実験結果の一例

今後の課題である.

\section{(2) 係留ワイヤに働く張力}

施工時における現地計測項目は，係留ワイヤに作用す る張力とし, 各ワイヤの新設函側の固定端部に取付けた 張力計で測定した. 現地計測に先立ち, 引き寄せワイヤ と振れ止めワイヤの効果を確認するために断面水路を用 いて子備実験を実施した. 図-3(a)に係留ワイヤの取付け
状況を示す.波向きに対して左側の2本のワイヤで係留索 をモデル化しており, ケースAEは引き寄せワイヤのみの 場合, ケースAGは振れ止めワイヤのみの場合である. な お右側の 2 本は模型の流出防止用として,十分に長いワイ ヤを配置した．各々のケースに対して複数の波高，周期 の規則波を作用させて，実験状況を撮影した映像から画 像解析により動摇量を算定した. 図-3(b)には摇れの定義, 図-3(c)に結果の一例として, 波浪周期と縦摇れの関係を 示す. 図より，振れ止めワイヤは引き寄せワイヤに比心 て，縦摇れの抑制効果が高いことが分かる．また上下摇 に対しても抑制効果が高いことを確認している.

\section{(3) ケーソンの動摇量}

計測器材の都合により，ケーソンの動摇量を直接計測 することができなかったため，据付作業への影響が少な い既設函上のやや離れた地点に固定したビデオ映像から 算定することとした．読取に用いた画像の一例を図-4に 示す．手前が既設函，奥が新設函である．新設函上の特 定の2点に着目し, コマ送りの静止画から位置を読み取つ た. そして水平および鉛直方向の変位量は, 2 点の各量の 平均值, 傾斜角は2点の傾きとして算定した. なお読夕取 り時刻は, 30秒の一定間隔に加え, 次に示寸ウィンチ操 作者への指示のタイミングとした。ただし動摇量測定を 目的として撮影した映像ではないため, 絶対值としての 精度は確保されていないことに留意が必要である。

\section{(4) ウィンチ操作者への指示}

ケーソン動摇量の読み取りに用いたビデオ映像から, ワイヤの動きも参考に， ウィンチ操作者への指示のタイ ミングと指示内容を可能な範囲で記録するものとした. 図-2および図-4に示寸通り，既設函に2台のウィンチが据 え付けられており,各々のウィンチには各1名のウィンチ 操作者が配置されていて，指示者の指示によって，引き 寄せワイヤあるいは振れ止めワイヤを制御する.

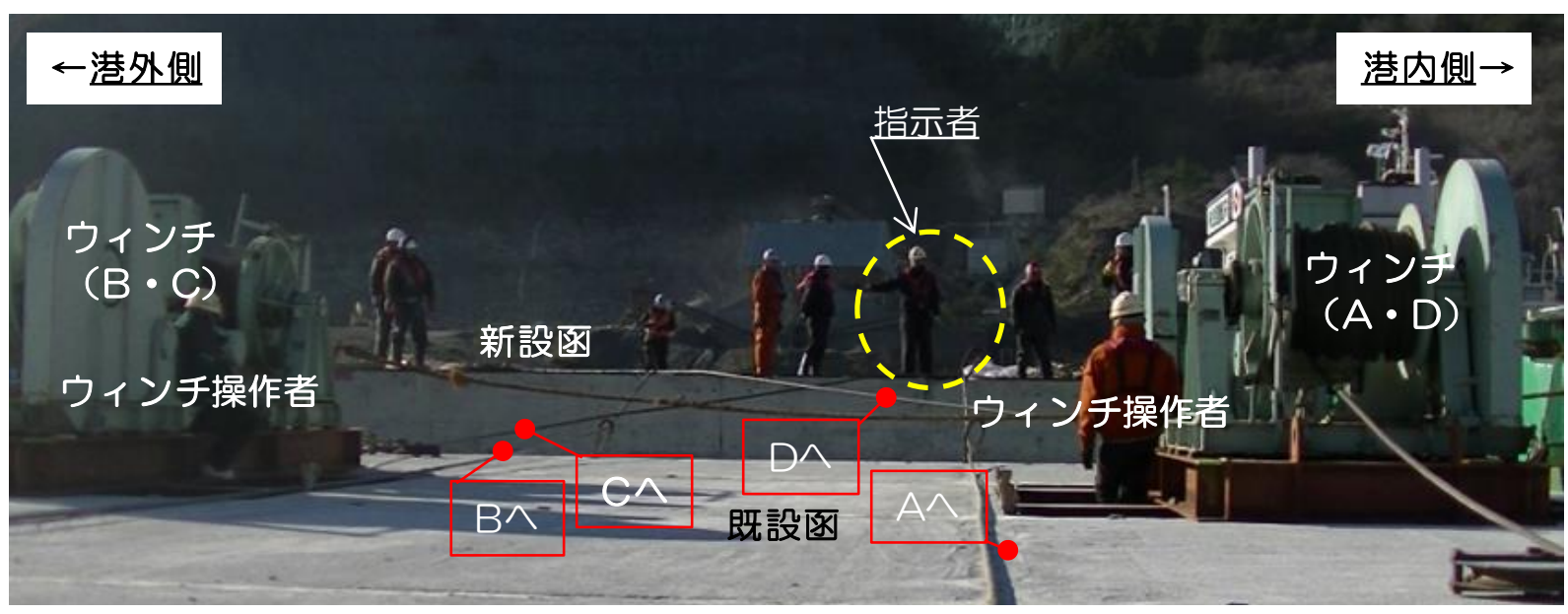

図-4＼cjkstart読み取りに用いた画像の一例 


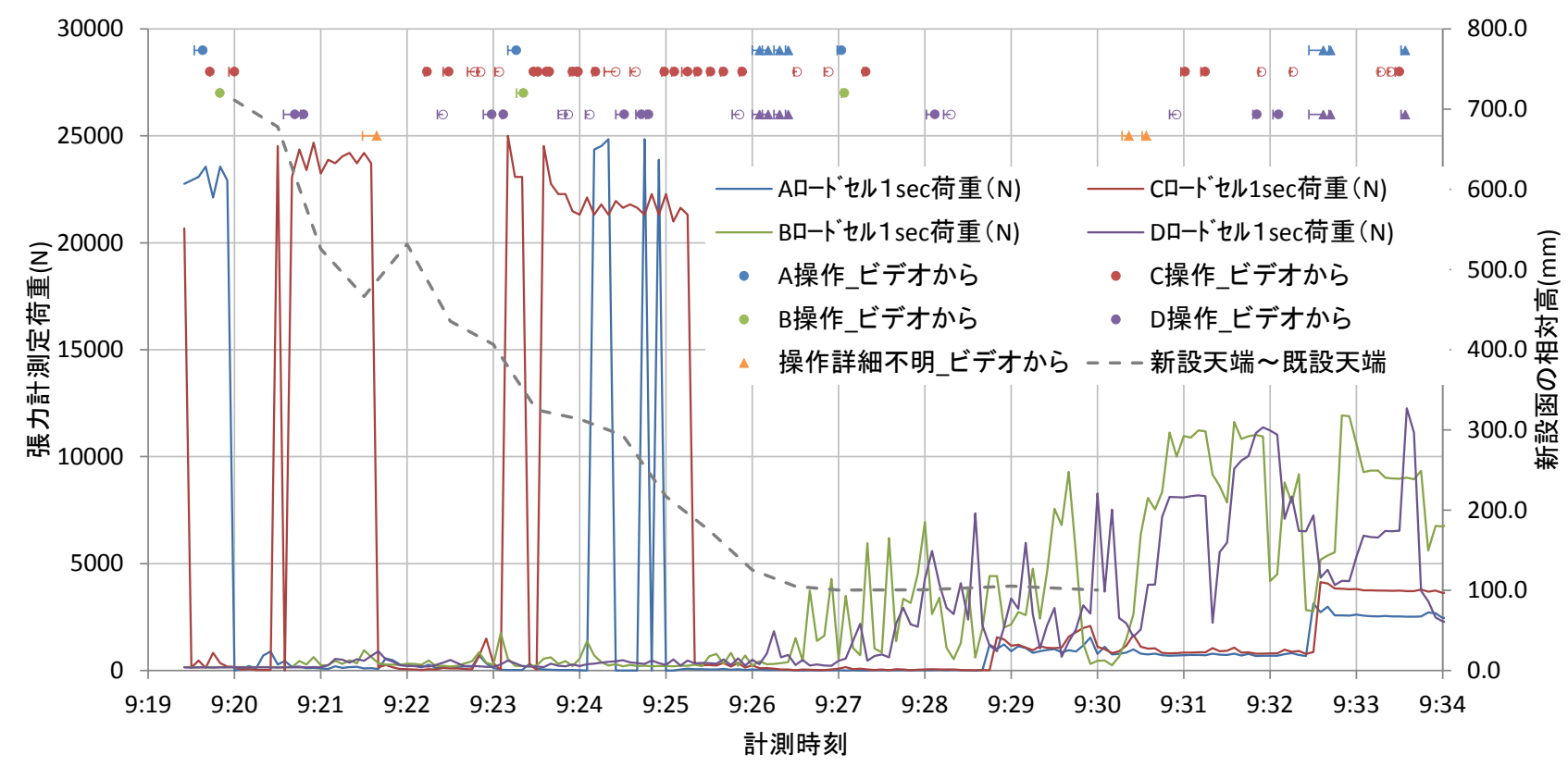

(a) 係留索に作用する張力変動

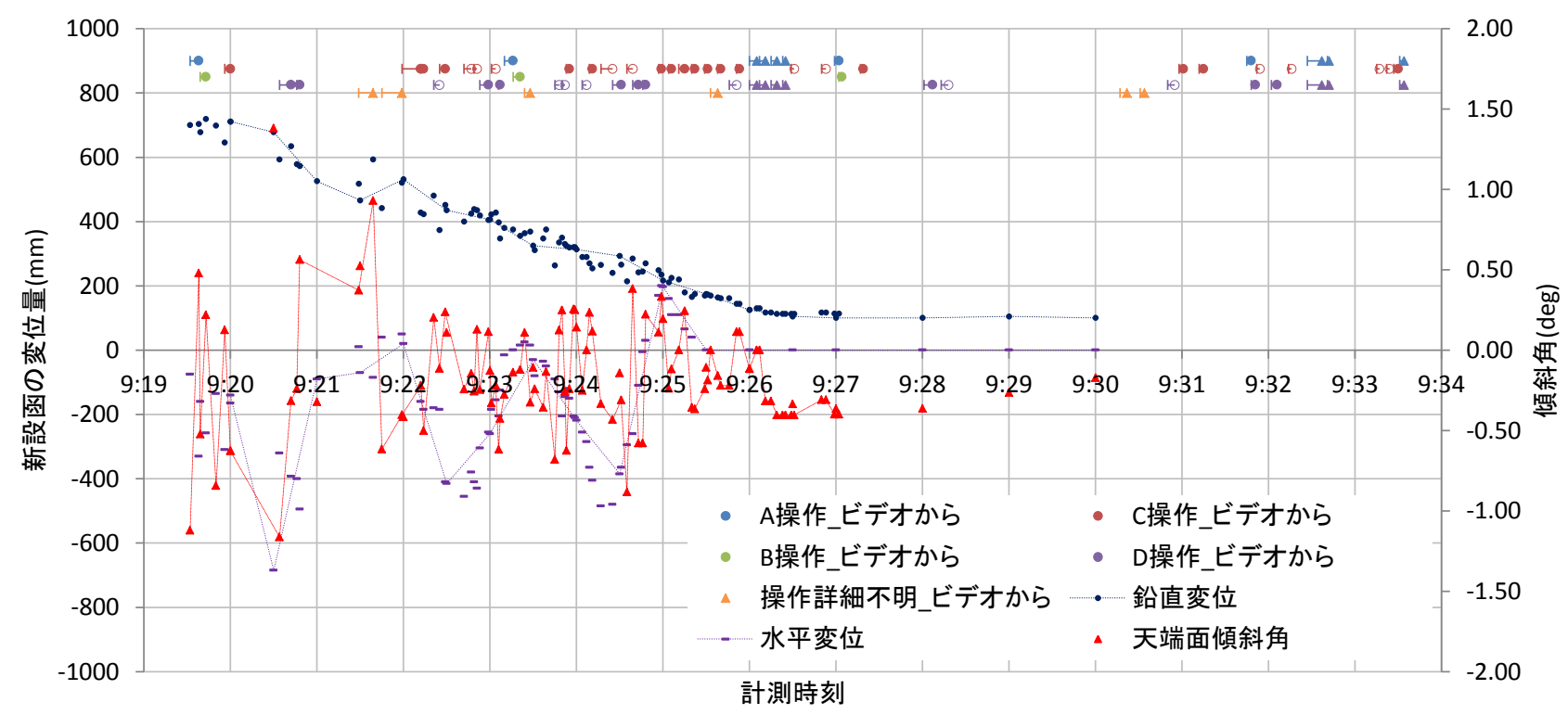

(b) 新設函の鉛直および水平 (正 : 港外側) 変位と傾斜角（正 : 反時計回り）の時間変動

図-5 ウィンチ操作者への指示状況と係留ワイヤに働く張力および新設函の動摇

(操作指示の塗潰しは引き込み指示，白抜きは送り出し指示，横線は指示の継続を示す）

\section{3. 計測結果}

\section{(1) 係留索に働く張力および新設函の動摇と指示}

現地計測は平成26年12月5日午前の新設函据付作業に 合せて実施した．図-5に，ウィンチ操作者への指示状況 と係留ワイヤに働く張力および新設函の動摇量の時間変 動を示す. 図-5(a)は係留ワイヤに取付けた張力計の測定 結果（左側縦連由）と既設函天端から新設函天端までの鉛 直位置（右側縦軸，新設函の相対高)，図-5(b)は新設函 の水平および鈆直方向の変位量 (左側縦軸) と傾斜角 (右 側緹軸) であり, ともに横軸は時刻である. 図-5(b)では,
各量に対して30秒間隔で読み取ったデータと，指示のタ イミングで読み取ったデータを同時にプロットしている. データの性格上，これらを線で結ぶことは適切ではない が，変動傾向の参考として，水平および鉛直変位につい ては30秒間隔，傾斜角は指示のタイミングのデータを点 線で結んでいる. また図-5(a)の新設函の相対高は図-5(b) の鉛直変位と同一である.

撮影を開始した9:19から9:27頃にかけては，鉛直変位 が徐々に減少しながら，水平方向には周期的な振動があ り，この時間帯は新設函に注水しながら引き寄せている 段階であることが分かる．9:27以降は鉛直，水平変位と 


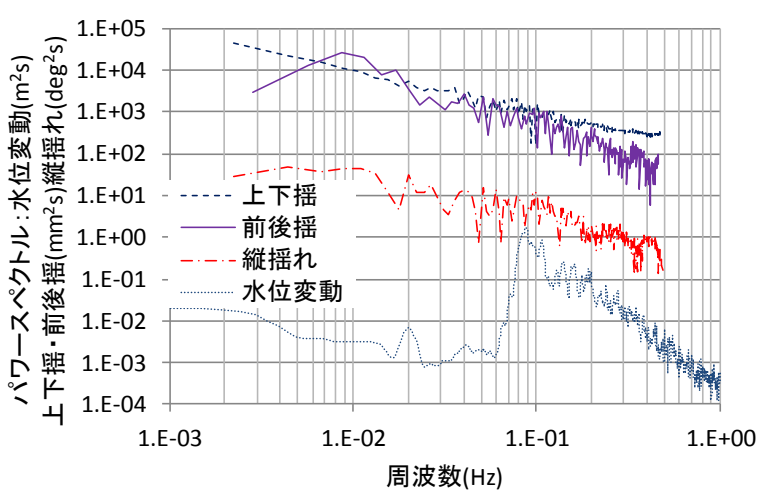

図-6 動摇諸量および水位変動の FFT 解析結果

も安定しており，新設函を所定位置に着底する段階であ ることが分かる．着底段階で一定の鉛直変位が残ってい るのは，撮影角の影響による読み取り誤差である。この 時, 係留ワイヤに作用する張力の変動と指示の状況に着 目寸ると，引き寄せ段階と着底段階で大きく傾向が異な つている.

まず引き寄せ時には指示の頻度が高く, 振れ止めワイ ヤ（張力計C）で波浪による港外側から港内側への動摇 を制御しながら，引き寄せワイヤ（張力計A）で新設函 を引き寄せようとしていることが分かる.この段階では, 新設函は浮体構造物の挙動を示し，図-5(b)で分かる通り， 水平変位や傾斜角が振動している。ここで波浪が防波堤 の法線にほぼ直角に入射すると仮定すると，波向きに対 して水平変位は前後摇(正が港外側), 傾斜角は縦摇れ (正 が反時計回り）に相当する．比較的大きな前後摇が観測 される9:25頃までは，港内側（前後摇が負）に新設函が 変位するタイミングで張力計Cに対応する振れ止めワイ ヤへの指示が頻繁に出されるとともに，前後摇がゼロに 近づくと，張力計Dに対応する振れ止めワイヤにも指示 が出されて, 振れを制御しようとしていることが伺える.

着底に向けた最終段階と推測される9:25頃から9:27頃 にかけては，4本のワイヤのいずれか1本，あるいは複数 に対して継続的に指示が出されており, 前後摇, 縦摇れ ともに小さな值となっている.

着底段階の9:27以降は, 引き寄せ段階とは異なる2本の ワイヤ (張力計B，Dに対応）操作により, 新設函の位置 決めをしているものと考えられる。この時，引き寄せ時 に作用する張力は着底時に作用する張力より大きい. こ の差が生じる要因としては，波浪外力や据付時の新設函 への注水に伴う質量増加，重心変化が推定される. 但し 今回の検討では原因の解明には到っておらず，今後の課 題である.

\section{（2）新設函の動摇と波浪外力}

当日午前 9 時の波浪条件は，ナウファス石巻港の速報 值》によると，有義波周期 $5.0 \mathrm{~s}$, 有義波高 $0.38 \mathrm{~m}$ であり,
施工に適した条件であった．ただしナウファス石巻港の 波浪計測地点は，女川湾と牡鹿半島により隔てられてお り，ナウファスデータが施工地点の波浪を直接的に示す ものではないと考えられたため, 据付場所から $200 \mathrm{~m}$ 沖側, 水深約 $20 \mathrm{~m}$ 付近の海底面に超音波水圧併用式波高計を設 置し, 1 時間ごとに正時を挟む20分間の波浪観測を行った。 平成26年12月5日8時50分から9時10分までの計測では, 有 義波周期 $4.0 \mathrm{~s}$ ，有義波高 $0.4 \mathrm{~m}$ である.

この観測值とケーソン動摇各諸量との関係を比較す るため, 各々の時間変動に対してFFT解析を行った. 結 果を図-6に示す．横軸は周波数，縦軸は各量のパワース ペクトルであり, FFT後のピリオドグラムを矩形フィル ターにより平滑化している. ケーソン動摇諸量に関して は，引き寄せ段階の時間帯を対象に，指示のタイミング で読み取った時間間隔の不均一なデータを補間，補外す ることによって，均一な時間間隔のデータに変換した後 にFFT解析した。 上下摇に関しては，時間変動を示寸図 -5(b)からも分かる通り, 明瞭なピークは存在していない 前後摇については, $0.01 \mathrm{~Hz}$ 付近にピークが存在しており, 図-5(b)の時間変動からも同程度の周期運動が確認でき る. 水位変動の解析結果からは明暸ではないものの, そ の付近の周波数帯で極大值が存在しており，波浪の長周 期成分に対寸る応答と考えられる。一方，水位変動がピ 一クを示す $0.1 \mathrm{~Hz}$ 付近では明膫な応答が見られない. 縦摇 れに関しては, 水位変動の0.1Hzおよび0.02Hz付近のピー クに対応する極大值が存在している.

以上より，今回計測対象とした施工可能な波浪条件下 において，縦摇れは風波領域の波浪，前後摇は長周期成 分の影響を受けるが，上下摇は影響を受けにくいことが 定性的に分かった。

なおケーソンの動摇諸量の解析結果については，デー 夕数の制約で，長周期（低周波数）側データの有意性が 確保されていないことに留意する必要がある。また係留 ケーブルを含めた新設函の固有周期については，本研究 では検討しておらず，今後の課題である.

\section{4. おわりに}

防波堤ケーソンの据付作業において係留ワイヤに作 用する張力の現地計測を行い，ビデオ映像からの読み取 つた新設函の動摇諸量や係留ワイヤのウィンチ操作への 指示との関係を調べた．結果は以下の通り．

(1) 今回の施工および波浪条件では，引き寄せ時と着底 時で大きな張力を生じるワイヤが異なり，引き寄せ時に より大きな張力が作用していた.

(2) 引き寄せ時の新設函は係留された浮体として動摇し, 防波堤法線に直角に入射寸る波浪に対して縦摇れは風波 領域の成分の影響を受け，前後摇は長周期成分の影響を 
受けるが，上下摇に対する波浪の影響は小さい.

(3) 係留ワイヤのウィンチ操作に対する指示は，引き寄 せ段階の前後摇に対応する水平変位が大きくなるタイミ ングで，振れ止めワイヤに対して出され，その後，水平 変位が大きくなると, 反対側の振れ止めワイヤに対して 指示が出される.

ただしここでの取りまとめは，1ケースの現地計測結 果を整理したに過ぎない. 本研究の目的は技術者経験值 の数值化であり,1ケースのみの取りまとめでは十分とい えない.さらに，実施工における起重機船の影響などを 考慮するためには，水理模型実験や数值解析などによる 起重機船の有無での比較検討なども有効と考えられる. そこで，今後は以下の計画により数值データとしての信 頼性を高める予定としている.

現地計測の実施

新たな現地計測では，ウインチ操作と張力変動および 動摇諸量との関係を明確にすることを目的に，据付作業 後に指示者にヒアリングを行うなど，データの信頼性向 上に努めるとともに，数多くのデータを蓄積する 水理模型実験の実施

実施工を単純化したモデルにより波浪と張力変動およ び動摇諸量との関係を求め, 現地計測との差異から, ウ インチ操作や起重機船などの影響を評価する

数值解析の実施

水理模型実験結果をもとに数值解析の精度確認を行い, 現地計測や水理模型実験では再現が難しい多様な条件下 での検討を行うことで，データの蓄積を図る
謝辞 : 本論文は，宮城県発注の女川湾口防波堤災害復旧

（その 5）工事において施工管理の一環として計測した データをとりまとめたものである. 宮城県, 石巻港湾事 務所の皆さまには，今後の現場精度の向上や若手技術者 の負担軽減を目的としての論文取りまとめにご快諾頂い たことを記して感謝の意を表する.

\section{参考文献}

1）堀沢真人，佐藤典之，大橋裕寿，赤村重紀，坂間茂， 吉倉敬治 : ケーソン沈設過程の波浪中挙動, 海岸工学 論文集，第 43 巻，pp.1001-1005， 1996.

2) 堀沢真人, 佐藤典之, 坂間茂, 矢口真光, 滑川正倫 : ケーソン据付時の動摇及び索張力に関する現地調査, 海洋開発論文集, Vol.13, pp.429-434, 1997.

3) 石見剛, 白石悟, 名里健吾 : 外洋に面した港湾におけ る防波堤ケーソンの据付時の動摇特性および作業限 界条件，港湾技研資料，No.850，29p，1996.

4) 米山治男 : 動摇シミュレーションによる防波堤ケーソ ンの据付限界状態に関する検討，海洋開発論文集，第 19 巻, pp.659-664, 2003.

5）石㠃崇志，倉田克彦，荒木英二 : ケーソンの据付時動 摇特性, 土木学会第 54 回年次学術講演会概要集, VI -223, pp.446-447, 1999.

6) 石㠃崇志, 荒木英二, 藤原隆一, 倉田克彦, 永田修一, 吉田尚史，田中洋 : ケーソンの曳航・据付時の動摇お よび索張力, 海岸工学論文集, 第 46 巻, pp.841-845, 1999.

7） ナウファス（全国港湾海洋波浪情報網）ホームペー ジ，過去データ， 2014 年連続データ（速報值） http://nowphas.mlit.go.jp/nowphasdata/static/sub320_201 4e.htm.

\title{
FIELD MEASUREMENT OF TENSION OF MOORING CABLES DURING INSTALLATION OF BREAKWATER CAISSON
}

\author{
Yasuo KOTAKE, Junya GOTO, Katsutoshi OGURA, Satoru ABE, \\ Yosuke YAMAGUCHI and Naoyuki KATO
}

Lack of technical experts and inheritance of skills to the next generation has been serious problems in construction sites. In this study, the authors try to quantify experiences and skills of technical experts on how to handle a mooring cable and how to operate a winch. In the trial, the tension in the mooring cable and the oscillation of the caisson were measured in installing caissons. The authors show that the cable with larger tension at the time when a caisson is drawn is different from that at the time at the time when a caisson is placed on a rubble mound under the conditions targeted in this study. They also show that the tension of each cable is the largest when a caisson is drawn. 